\title{
MULTIKULTURALISME \\ DALAM \\ WACANA ALQURAN
}

\author{
Rusli \\ STAIN Datokarama Jl. Diponegoro No. 23 Palu \\ Email: rusli_mochtar@yahoo.com
}

\begin{abstract}
Abstrak: Artikel ini membahas konsep multikulturalisme dari sudut pandang Alquran. dikatakan bahwa semenjak awal, Alquran telah mengenal dan menghargai perbedaan berbasis ras, agama, budaya, dan sebagainya. Bahkan, Alquran itu sendiri diwahyukan dalam konteks multikultural. Dasar epistemologis bagi multikulturalisme dalam wacana Alquran adalah "kemuliaan manusia”, yang darinya muncul seperangkat hak asasi yang harus dihormati dan dilindungi, yang merupakan fondasi etis bagi multikulturalisme. Sebagai konsekuensi dari penjagaan terhadap hak-hak ini muncul konsep keadilan dan kesetaraan. Karena manusia diciptakan mulia dan mempunyai kesamaan kemanusiaan, maka pencederaan terhadapnya dan juga hakhaknya merupakan pelanggaran terhadap kemanusiaan universal tersebut. Karenanya, untuk mencapai perdamaian di antara mereka, toleransi menjadi sebuah keharusan. Untuk melakukan hal itu, maka strategi anti-diskriminasi dan penghilangan prasangka negatif terhadap setiap kelompok yang berbedaetnik, ras, budaya, dan agama-menjadi penting untuk dibentuk berdasarkan cara yang disesuaikan dengan konteks setempat.
\end{abstract}

Abstract: The paper deals with the concept of multiculturalism from the Quranic perspective. It is argued that since the beginning, the Quran recognised and appreciated diversity based on race, religion, culture, and so on. Even, the Quran itself was revealed in the multicultural context. The epistemological basis for multiculturalism in the discourse of the Quran is "human dignity", from which emerge a set of basic rights that must be respected and protected, which becomes an ethical foundation of multiculturalism. As a consequence of protecting the basic rights, the concept of justice and equality comes to surface. Since human beings are created as sacred and equal, hurting them and 
their rights is violation to universal humanity. Therefore, to achieve peace, toleration is necessary. To do this task, the strategy of anti-discrimination and prejudice reduction to different groups based on ethnicity, race, culture, and religion-is highly necessary to be established according to local context.

Kata Kunci: Alquran, multikulturalisme, hak asasi manusia, keadilan, toleransi, dialog

\section{PENDAHULUAN}

"Multikulturalisme" menjadi isu yang diperbincangkan hangat dalam berbagai perspektif keilmuan saat ini baik dari sudut pandang pendidikan, psikologi, sosiologi, antropologi, maupun hukum Islam. Namun, yang mencoba memperbincangkannya dalam perspektif Alquran mungkin belum begitu banyak dilakukan. Artikel ini berupaya membahas bagaimana Alquran berbicara tentang gagasan multikulturalisme. Pendekatan yang digunakan adalah pendekatan tafsir dengan berpijak pada prinsip fenomenologi, yang menekankan pada asumsi "membiarkan Alquran berbicara sendiri tentang persoalan ini."

Dalam menafsirkan Alquran tentang "multikulturalisme", ada dua hal yang penting untuk diperhatikan. Pertama, Alquran tidak hanya berbicara kepada umat Islam tapi berbicara kepada banyak umat, seperti Nasrani, Yahudi, kaum musyrik Mekkah, dan lain-lain. Dalam Alquran juga terdapat ungkapan-ungkapan yang diarahkan kepada berbagai komunitas yang berbeda, seperti "hai orang-orang beriman" (yā ayyuhā al-ladhīna āmanū) "hai manusia" (yā ayyuhā al-nās), "hai orang-orang kafir" (yā ayyuhā al-kāfirūn), dan sebagainya, yang membuktikan bahwa Alquran pada saat itu memang tidak hanya berbicara pada satu komunitas agama saja, yaitu umat Islam, namun juga berbicara kepada banyak pihak. Kedua, Alquran berbicara tentang hal-hal yang bersifat multikulturalistik. Banyak suara yang direfleksikan oleh Alquran, dan banyak representasi, ada suara untuk Muhammad, 
ada suara yang disampaikan Allah sendiri, dan juga ada suara yang disampaikan kepada umat manusia yang lain.

Intinya, Alquran semenjak awal telah mengenal gagasan tentang multikulturalisme, dalam arti keragaman budaya berbasis agama, etnisitas, dan lain-lain. Bahkan secara normatif, Alquran mengakui bahwa manusia dijadikan berbangsa-bangsa ( $s h u^{t} u \bar{b}$ ) dan bersuku-suku ( $q a b \bar{a}$ 'il) dengan tujuan agar mereka saling mengenal dan menghargai satu sama lain (Q.S. al-Hujurāt [49]: 13). Seandainya Allah menghendaki, tentu Ia akan menjadikan hanya satu umat (Q.S. al-Shūrā [42]: 8).

Lalu, bagaimana Alquran melihat konsep "multikuluralisme" secara holistik. Tulisan ini mencoba melihat gagasan-gagasan universal dalam Alquran yang menjadi fondasi bagi pembangunan masyarakat yang multikulturalis atau masyarakat madani yang mengakui dan menghargai perbedaan, seperti tertuang dalam Piagam Madinah. Sebelum melihat bagaimana Alquran berbicara tentang konsep ini, terlebih dahulu perlu memahami konsep multikulturalisme dan akar-akar yang memperkuat konsep ini.

\section{MULTIKULTURALISME: AKAR DAN REALITAS}

"Multikulturalisme" secara sederhana diartikan sebagai "keragaman budaya". Ada tiga istilah yang biasa digunakan untuk melukiskan keragaman baik yang berbasis pada agama, ras, etnisitas, bahasa, maupun budaya, yaitu pluralitas (plurality), keragaman (diversity) dan multikultural (multicultural). Namun semuanya tidak mempunyai konotasi yang sama. Multikulturalisme dipahami sebagai

"sebuah sistem keyakinan dan perilaku yang mengenali dan menghormati keberadaan semua kelompok yang berbeda dalam sebuah organisasi atau masyarakat, mengakui dan menghargai perbedaanperbedaan sosial budaya, dan mendorong dan memungkinkan

${ }^{1}$ Tim Redaksi Bahasa Indonesia, Kamus Besar Bahasa Indonesia (Jakarta: Pusat Bahasa, 2008), h. 980. 
kontribusi mereka yang berkesinambungan dalam sebuah konteks budaya yang inklusif yang memberdayakan semua dalam sebuah organisasi atau masyarakat itu." ${ }^{2}$

Multikulturalisme dapat diartikan juga sebagai "gerakan sosialintelektual yang mengangkat nilai perbedaan sebagai prinsip inti dan menegaskan bahwa semua kelompok budaya harus diperlakukan dengan rasa hormat dan sama."

Secara filosofis, multikulturalisme ini berangkat dari asumsi tentang kemuliaan dan kehormatan manusia (human dignity). Dan prinsip ini terdapat dalam semua agama besar dunia. Karena manusia itu mempunyai posisi yang mulia, maka hak-hak yang melekat pada mereka harus dihormati dan dijaga. Penodaan dan pelanggaran terhadap hak-hak asasi tersebut adalah penindasan terhadap kemanusiaan universal. Maka, setiap perbedaan yang terjadi jangan mengantarkan kepada konflik yang dapat mencederai hak-hak asasi manusia. Untuk itu, toleransi adalah sebuah keharusan untuk menghargai perbedaanperbedaan tersebut, dengan cara berdialog dan menghilangkan diskriminasi dan prasangka buruk dalam pergaulan.

Sebagai sebuah paradigma, multikulturalisme memuat dalam dirinya nilai-nilai etis, yang menjadi pedoman dasar dalam setiap perilaku individu. Dalam pedoman tersebut terdapat prinsip-prinsip moral yang menjamin setiap aktivitas individu dan masyarakat sesuai dengan hak dan kewajibannya. Prinsipprinsip moral tersebut mencakup politik dan demokrasi, keadilan dan penegakan hukum, kesempatan kerja dan berusaha, hak asasi manusia, hak budaya komunitas dan kelompok minoritas, dan lain-lain. Oleh karena itu, multikulturalisme dapat dikatakan sebagai gerakan etis.

${ }^{2}$ Caleb Rosado, "Toward a Definition of Multiculturalism" (28 October 2006) dalam http://rosado.net/pdf/Def_of_Multiculturalism.pdf. (Diakses: 21 Februari 2012).

${ }^{3}$ Blaine J. Fowers dan Frank C. Richardson, "Why Is Multiculturalism Good?" American Psychologist, Vol. 51, No. 6 (June 1996), h. 609. 


\section{ALQURAN TENTANG MULTIKULTURALISME}

Keragaman (diversity) adalah sentral bagi pandangan Alquran tentang masyarakat. Alquran mengakui keragaman ini dengan menyatakan kepada Nabi Muhammad bahwa jika Allah ingin, tentu Ia akan menjadikan hanya satu umat (Q.S. al-Mā’idah [5]: 48). Namun, manusia dijadikan 'berbangsa-bangsa dan bersuku-suku' sehingga mereka saling mengenal (Q.S. al-Hujurāt [49]: 13). Kemudian, Alquran mendorong masing-masing individu untuk saling mengenal, baik Muslim maupun non-Muslim, yang mempunyai kepercayaan yang berbeda dari mereka, dan berlomba-lomba melakukan kebaikan (Q.S. al-Mā’idah [5]: 48). Etika abadi ini berakar pada gagasan Alquran tentang kesamaan manusia, yang menekankan bahwa semua manusia, tanpa melihat persuasi ideologisnya, diciptakan dari 'jiwa yang sama' (nafs wāhidah) (Q.S. al-Nisā' [4]: 1). Karena itu, tidak menjadi penting apakah ia seorang Yahudi, Kristen, atau Sabiun, karena siapa pun yang melakukan kebaikan 'akan mendapatkan ganjarannya dari Allah' (Q.S. al-Baqarah [2]: 62). Bahkan, 'orang yang paling mulia', menurut Alquran adalah 'yang paling bertakwa' (Q.S. al-Hujurāt [49]: 13).

Alquran kemudian menyatakan bahwa penilaian manusia itu bergantung pada kebajikannya, bukan pada keterikatannya dengan satu keyakinan tertentu. Kesalehan itu menyebar melalui tindakan sosial-cara terbaik untuk mengabdi kepada Allah adalah melayani kemanusiaan. Maka, seruan untuk menegakan keadilan sosial adalah fondasi dari komunitas multikultural yang inklusif (ummah muqtașidah), yang terdiri dari beragam manusia yang berbeda-beda, yang disatukan oleh etika Adamik tentang tanggung jawab ganda manusia untuk menghormati dan menghargai diri dan masyarakat.

Pandangan Alquran tentang keragaman ini, yang diikat oleh pandangan tentang kesamaan manusia, mempengaruhi tindakan dan relasi Nabi dengan komunitas-komunitas lain. Maka, dapat 
kita lihat nanti bahwa Nabi, yang akhlaknya adalah Alquran, memperkuat dan menyebarkan nilai-nilai universal Alquran, yang menjadi fondasi bagi multikulturalisme, yaitu keadilan (justice), kesetaraan (equality), hak asasi manusia (human rights), nilainilai demokratis (democratic values), yang kemudian memunculkan berbagai sikap seperti anti diskriminasi, prasangka (prejudice), dan toleransi, terhadap kelompok-kelompok yang berbeda baik atas dasar ras, etnisitas, agama, budaya, dan lainlain. Lihat bagan berikut ini!

Bagan 1: Multikulturalisme dalam Alquran

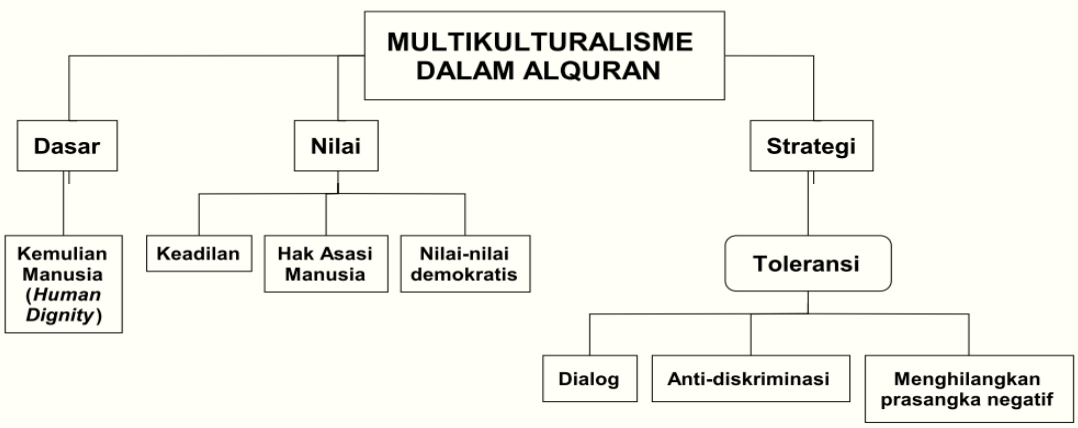

\section{Keadilan dan Kesetaraan bagi Semua Orang}

'Adl, yang diartikan sebagai keadilan, ditemukan empat belas kali dalam Alquran. Ia juga merupakan sifat Allah, yang mengilustrasikan tindakan Allah sebagai penguasa dan hakim yang adil. ${ }^{4}$ Kata kerja 'adala, yang mengandung arti "bertindak secara adil", pada umumnya berhubungan pula dengan konsepkonsep kesetaraan dan keseimbangan.

Dalam Alquran, konsep 'adl dikaitkan dengan Tuhan dan manusia. Pertama menggambarkan tentang keadilan Tuhan (Q.S. Āli 'Imrān [3]: 18; Yūsuf [12]: 80), dan kedua tentang keadilan

${ }^{4}$ Oliver Leaman (ed), The Qur'an: An Encyclopedia (London and New York: Routledge, 2006), 13.

${ }^{5}$ Hans Wehr, A Dictionary of Modern Written Arabic, ed. J. Milton Cowan, Edisi 3 (New York: Spoken Language Services, 1976), 596. 
manusia, yaitu anjuran agar manusia berlaku adil dalam setiap aspek, kepada Tuhan, manusia dan lingkungan. Agar dapat dikatakan adil kepada Tuhan, manusia harus menjadi saleh dan bermoral dan memenuhi tujuan penciptaannya, yaitu menyembah Tuhan (Q.S. al-ẓāriyāt [51]: 56). Agar dapat dikatakan adil kepada sesama manusia, manusia harus memberikan setiap haknya dan bertindak terhadap makhluk-makhluk tersebut sesuai dengan hak-hak mereka (QS. al-Mā'idah [5]: 8; al-A'rāf [7]: 29; alMumtahanah [60]: 8). ${ }^{6}$ Tuhan memerintahkan umat manusia tidak hanya untuk berlaku adil, tetapi juga berkata adil (Q.S. al-An'ām [6]: 152), serta memutuskan perkara dengan adil (Q.S. al-Nisā' [4]: $58)$.

Perlawanan terhadap ketidakadilan (zulm), ketertindasan dan kejahatan berbasis apa pun-apakah itu ras, etnisitas, gender, agama, sosial-budaya atau pun ideologi politik-adalah suatu keadilan dan merupakan cara untuk menegakkan keadilan. Dan orang-orang yang tidak adil dan melakukan penindasan berarti memutuskan perjanjian dan ikatan dengan Tuhan (Q.S. alBaqarah [2]: 124), dan bahkan Tuhan tidak menyukai orang-orang tersebut (Q.S. 'Āli 'Imrān [3]: 57). Dengan demikian, dapat disimpulkan bahwa menurut prinsip Alquran, hidup dan berbuat adil berarti juga memerangi penindasan, kejahatan dan ketidakadilan.

\section{Hak Asasi Manusia}

Dalam pandangan Alquran, manusia mempunyai kemuliaan (dignity, karāmah). Oleh karena itu, prasyarat bagi kemuliaan manusia itu diberikan perhatian yang serius dalam berbagai regulasi hukum Islam, dan tidak ada satu pun aturan yang tidak sesuai dengan kemuliaan manusia tersebut. Hak untuk hidup, mempunyai kebebasan, beragama dan menikmati manfaatmanfaat sosial adalah prasyarat bagi kemuliaan manusia dalam

6 Seyyed Hossein Nasr, The Heart of Islam: Enduring Values for Humanity (New York: Harper Collins, 2002), 249 
pandangan Alquran, dan tidak ada seorang pun punya hak untuk membahayakan dan mengancam kemuliaan manusia.

Terkait dengan hak untuk hidup, Alquran menjunjung tinggi kemuliaan dan nilai absolut kehidupan manusia (Q.S. alAn‘ām (6): 151), dan menjelaskan bahwa, secara esensial, kehidupan masing-masing individu sama dengan kehidupan semua komunitas dan, karenanya, harus diperlakukan dengan penuh perhatian (Q.S. al-Mā’idah [5]: 32).

Begitu pula, mengenai hak untuk mendapatkan penghormatan, Alquran menganggap semua manusia berhak mendapatkan penghormatan (Q.S. al-Isrā' [17]: 70). Manusia dapat mengelola kebebasan berkehendak karena mereka mempunyai potensi akal, yang membedakan mereka dari semua makhluk (Q.S. al-Baqarah [2]: 30-34). Meskipun manusia dapat menjadi yang paling rendah (asfal al-sāfilinn), namun Alquran menyatakan bahwa mereka tercipta dalam "bentuk yang terbaik" (ahsan altaqwīm) (Q.S. al-Ṭin [95] 4-6), karena mempunyai kemampuan untuk berpikir, mengetahui baik dan buruk, melakukan kebaikan dan menjauhi keburukan. Oleh karena itu, berdasarkan janji manusia sebagai khalifah Tuhan di muka bumi, kemanusiaan semua umat manusia harus dihormati dan dianggap sebagai tujuan dalam dirinya.

Mengenai hak untuk mendapatkan kebebasan, Alquran sangat peduli dengan pembebasan manusia dari segala bentuk belenggu. Karena mengetahui kecenderungan manusia untuk bersikap diktator dan tiran, Alquran mengatakan dengan jelas dan penuh penekanan dalam surat Āli 'Imrān [3]: 79 bahwa "Tidak wajar bagi seorang manusia yang diberikan al-Kitāb oleh Allah, hikmah dan kenabian, kemudian berkata kepada manusia 'Hendaklah kamu menjadi penyembah-penyembahku ('ibād) selain Allah ..."

Penghapusan perbudakan manusia, tentu saja, menjadi sangat penting dalam konteks kebebasan manusia. Perbudakan telah meluas di Arabia pada saat datangnya Islam, dan perekonomian Arab juga didasari padanya. Alquran tidak hanya bersikukuh bahwa budak mesti diperlakukan secara adil dan 
manusiawi (Q.S. al-Nisā' [4]: 36), namun juga mendorong untuk membebaskan budak (Q.S. al-Baqarah [2]: 177; al-Nisā' [4]: 92; alMā'idah [5]: 89).

Jaminan terbesar bagi kebebasan pribadi bagi seorang Muslim terletak pada ketentuan Alquran bahwa hanya Tuhan yang dapat membatasi kebebasan manusia (Q.S. al-Shūrā [42]: 21) dan pada pernyataan bahwa "penilaian (baik dan buruk) berada pada Tuhan sendiri” (Q.S. Yūsuf [12]: 40).

Terkait dengan hak untuk mendapatkan pengetahuan, Alquran menekankan pentingnya perolehan pengetahuan (QS. al'Alaq [95]: 1-5). Setelah bertanya secara retorik apakah mereka yang tidak berpengetahuan sama dengan yang berilmu (QS alZumar [39]: 9), Alquran mendorong umat beriman untuk menambah ilmu pengetahuan (Q.S. Țāhā [20]: 114). Menurut perspektif Alquran, ilmu pengetahuan adalah prasyarat untuk menciptakan dunia yang adil yang di dalamnya perdamaian dapat eksis. Alquran menekankan pentingnya pencarian ilmu bahkan pada masa perang (Q.S. al-Tawbah [9]: 122)

\section{Toleransi dan Dialog Keagamaan}

Toleransi merupakan prasyarat penting untuk kehidupan bersama bagi kelompok-kelompok orang yang berbeda sosial, budaya dan agamanya, meskipun perbedaan-perbedaan tersebut mungkin tidak disetujui oleh pihak-pihak yang bersangkutan. Alquran memandang toleransi sebagai titik tolak yang penting dalam membangun perdamaian yang lebih besar. Alquran mencoba membangun perdamaian antara komunitas agama yang berbeda dan mengakui perbedaan keyakinan dan budaya. Ia meletakkan penekanan yang besar pada pemeliharaan hubungan yang baik antara penganut agama yang berbeda karena, menurut Alquran, kebebasan agama adalah basis bagi perdamaian yang berkelanjutan. Alquran menyeru semua orang yang beriman untuk "masuk ke dalam perdamaian dan tidak mengikuti langkah setan" (Q.S. al-Baqarah [2]: 208). Aspek ini ditekankan dalam wacana Alquran tentang toleransi. Keragaman diakui dan sangat 
dihargai dalam Alquran. Misalnya, surat al-Rūm [30]: 22 menegaskan bahwa dalam keragaman tersebut ada tanda-tanda Allah bagi mereka yang mempunyai pandangan yang jelas dan bijaksana. Ini menyiratkan bahwa perbedaan-perbedaan tidak hanya diharapkan, namun juga ditolerir.

Dari pengakuan terhadap adanya perbedaan hingga pengusungan etos pluralisme, Alquran membuat standar yang kuat bagi semua orang-Muslim dan non-Muslim, berdasarkan pada nilai-nilai universal keadilan dan persamaan. Bagi Alquran, perdamaian adalah tujuan yang paling tinggi, dan jika perdamaian adalah suatu keharusan, maka yang pertama harus ada adalah toleransi, termasuk terhadap komunitas agama yang berbeda. Fondasi yang kuat bagi toleransi Alquran dapat dilihat dalam surat al-Isrā' [17]: 70 yang menegaskan bahwa manusia diberikan posisi yang mulia di antara makluk ciptaan-Nya. Ini diikuti oleh tanggung jawab untuk memelihara semua ciptaan oleh manusia sebagai khalifah di muka bumi. Surat al-Mā'idah [5]: 32 dan al-An'ām [6]: 98 berbicara tentang kesamaan asal muasal manusia yang membuat semua manusia saling berhubungan. Oleh karena itu, meskipun ada perbedaan-perbedaan, berbagai macam kelompok etnik dan keagamaan didorong untuk melihat gambaran yang lebih besar dan melampaui loyalitas-loyalitas 'kesukuan' yang memisahkan mereka.

Toleransi berhubungan dengan keadilan dan persamaan. Nabi diperintahkan oleh Alquran untuk berlaku adil terhadap manusia, dan teladan ini harus diikuti oleh umat Islam (Q.S. alNisā’ [4]: 135; al-Mā’idah [5]: 8; al-Mumtahanah [60]: 8). Namun demikian, tidak seorang manusia pun yang mampu dan berada dalam posisi menilai orang lain. Penilaian itu adalah milik Allah sendiri dan masing-masing akan mendapatkan pahala dari Allah berdasarkan hasil kerja mereka. Penekanan terhadap keadilan tidak meletakkan batasan-batasan pada toleransi terhadap yang lain, bahkan mereka yang melanggar hak-hak orang lain. Toleransi dapat dilihat dari kehidupan Nabi Muhammad, yang 
berbagai kebijakannya merefleksikan pandangan toleransi terhadap yang lain. Contoh dari toleransi ini adalah Piagam Madinah, yang menganggap Muslim, Yahudi dan kelompok musyrik lainnya sebagai "satu komunitas" yang berbagi tugas untuk saling melindungi satu sama lain dari serangan musuh, yang masing-masing memperoleh hak kebebasan beragama. Toleransi dalam Alquran, karenanya, dipandang hanya sebagai permulaan untuk mewujudkan perdamaian yang berkelanjutan antara berbagai komunitas yang berbeda.

Untuk itu, Alquran menyerukan untuk terlibat dalam dialog dengan yang lain, khususnya ahl al-kitāb. Misalnya, Alquran (surat Āli 'Imrān [3]: 64) menginstruksikan kepada umat Islam dan ahl al-kitāb untuk kembali kepada kalimat yang sama (kalimah sawā), yaitu "tidak menyembah kecuali hanya kepada Allah dan tidak menyekutukannya." Dalam berdialog, Alquran menganjurkan untuk menggunakan metode hikmah dan nasehat yang baik (Q.S. al-Nahl [16]: 125). Berdasarkan hal ini, pemaksaan terhadap kelompok agama yang lain menjadi tidak dibenarkan (Q.S. al-Baqarah [2]: 256).

Dalam sejarah, toleransi terhadap orang-orang yang berbeda budaya, bahasa dan keyakinan, ditekankan dalam Alquran. Pada tahun-tahun pertama Islam, popularitas dan kebertahanan Islam bergantung pada kelenturan yang ditunjukkan Islam kepada penduduk di wilayah-wilayah yang berbeda yang berada dalam kekuasaan Muslim. Para sejarawan menunjukkan satu contoh tentang pendekatan tersebut pada abad ke-8 dan ke-9 ketika mayoritas penduduk non-Muslim berada dalam kekuasaan politik Islam. Non-Muslim memperoleh hak-hak budaya dan etnik selama beberapa abad tanpa merasa perlu masuk ke dalam agama para penguasanya. 
Menurut Jacques Waardenburg, ${ }^{7}$ selama fase tersebut, yaitu ekspansi dan penaklukan ke luar Arabia, umat Islam menjumpai berbagai komunitas agama seperti, Mazdaean di Mesopotamia dan Iran; Kristen dalam berbagai varitasnya (Nestorian di Mesopotamia dan Iran, Monophysite di Syria, Mesir dan Armenia, Melkite Ortodoks di Syria, Latin Ortodoks di Afrika Utara, Arian di Spanyol); Yahudi di Mesopotamia, Iran, Syria dan Mesir; Samaritan di Palestina; Mandaean di Mesopotamia Selatan; Harranian di Mesopotamia dan Mesir; Budha dan Hindu di Sind; para pengikut agama-agama suku di Afrika Timur.

\section{TEOLOGI ISLAM MULTIKULTURAL BERBASIS ALQURAN}

Sebagai sebuah kitab suci yang menjadi petunjuk buat manusia (hudā li al-nās), Alquran menawarkan ajaran-ajaran humanis yang paripurna. Terkait dengan penciptaan masyarakat yang damai yang menghargai perbedaan-perbedaan, Alquran mempunyai ajaran-ajaran, yang dapat dibagi kepada tiga kelompok: nilai-nilai dasar, tujuan, dan implementasinya.

Nilai-nilai dasar yang dikandung oleh Islam dalam Alquran adalah keesaan Allah (tawhīd), keadilan ('adl), kasih sayang (rahmah), persamaan (musāwāh), dan ketakwaan (taqwā). Nilainilai ini adalah jantung bagi tradisi keagamaan Islam, dan berdasarkan nilai-nilai ini masyarakat Madinah dibangun. Keadilan dan kasih sayang merupakan sifat Allah, yang manusia diharuskan untuk meniru sifat-sifat ini. Agar dapat dianggap adil terhadap sesama, manusia harus memberikan hak-hak mereka dan bertindak sesuai dengan hak-hak tersebut. Jika tidak, maka mereka dianggap sebagai zalim, dan Allah tidak menyukai orangorang yang berlaku zalim.

Sementara itu, kasih sayang adalah tujuan dari diutusnya Nabi Muhammad Saw ke muka bumi ini. Dalam Alquran disebutkan wa mā arsalnāka illā raḥmatan li al-‘̄lamīn (Tidaklah

${ }^{7}$ Dikutip dalam Harold Coward, Pluralism in the World Religions (Oxford: Oneworld, 2000), 62-63. 
kami mengutusmu kecuali sebagai kasih sayang bagi semesta alam). Kasih sayang tersebut dapat diindikasikan oleh beberapa tanda berikut: berkata dan bersikap lemah lembut; tidak menyakiti baik secara fisik, psikologis, lisan, maupun lainnya; membantu kesulitan orang lain; melindungi orang yang lemah; tidak merusak lingkungan ekologis; tidak mengganggu binatang.

Dari prinsip-prinsip ini berbagai implementasi dilakukan untuk mencapai suatu tujuan, yaitu menciptakan "kondisi masyarakat yang makmur, adil, damai, dan harmonis." Untuk mencapai prinsip-prinsip tersebut, Alquran menawarkan beberapa cara, di antaranya adalah:

- Saling mengenali (ta'āruf) dan berbuat baik (ihsān), yaitu kesadaran dan keinginan untuk hidup bersama, bertetangga dengan orang lain yang berasal dari budaya, kelompok etnik, dan agama yang berbeda, untuk memperluas horison sosial (hidup berdampingan); bekerja sama, menerima dan memberi, dan siap untuk berkurban.

- Saling memahami (tafāhum), yaitu kesadaran bahwa nilai-nilai yang kita dan mereka miliki mungkin berbeda, dan kita dapat saling melengkapi, serta memberikan sumbangsih bagi hubungan yang dinamis dengan menegaskan bahwa orang lain yang berbeda dengan kita adalah teman kita. Teman sejati adalah teman dalam dialog, yang selalu memperlihatkan komitmen bersama untuk mencapai satu platform bersama, dan memahami perbedaan, kesamaan dan keunikan mereka.

- Saling menghormati (takrim), yaitu setiap orang harus mempersiapkan dirinya untuk mendengar pandanganpandangan dan suara-suara yang berbeda; menghormati kemuliaan dari berbagai macam individu dan kelompok.

- Berlomba dalam kebaikan (fastabiqū al-khayrāt); kesetaraan dalam perbedaan mendukung komunikasi dan persaingan yang sehat di kalangan individu dan kelompok untuk mencapai kualitas yang lebih tinggi dalam semua aspek kehidupan sosial. 
- Saling percaya (amānah), yaitu menjamin dan memelihara rasa dan sikap saling percaya dalam relasi antar manusia.

- Berbaik sangka (husn al-zann), yaitu mempunyai pikiran positif (positive thinking), dalam arti, bersikap hati-hati dalam menilai seseorang/sesuatu, dan berusaha mencari klarifikasi terhadap pemaknaan orang lain.

- Toleransi (tasāmuh), yaitu bersikap hormat terhadap setiap perbedaan baik dalam agama, pandangan budaya, dan kelompok etnik.

- Pemberian maaf ('afw, maghfirah), yang berarti melupakan semua kekerasan, kejahatan dan kesalahan yang pernah dilakukan oleh orang lain apakah karena disengaja atau tidak.

Nilai-nilai di atas menjadi menjadi karakteristik pedidikan Islam berbasis teologi multikulturalis, yang dapat didefinisikan secara operasional ke dalam beberapa praktik berikut ini: bagaimana hidup dan bekerja bersama-sama; dengan cara mengembangkan toleransi, mengklarifikasi nilai-nilai hidup bersama, bersikap matang secara emosional, berpartisipasi secara setara, dan membangun kontrak sosial baru dan memformulasi aturan-aturan kehidupan antara masyarakat yang berbeda; membangun sikap saling percaya; menjaga sikap saling memahami; mengembangkan sikap saling menghormati; bersikap terbuka terhadap segala perbedaan; saling ketergantungan kepada orang lain; dan memberikan resolusi konflik, atau gerakan nir-kekerasan, dan rekonsiliasi. ${ }^{8}$

\section{KESIMPULAN}

Dasar epistemologis bagi multikulturalisme dalam wacana Alquran adalah "kemuliaan manusia", yang darinya muncul

\footnotetext{
${ }^{8}$ Lihat Zakiyuddin Baidhawy, "Building Harmony and Peace through Multiculturalist Theology-Based Religious Education: An Alternative for Contemporary Indonesia," British Journal of Religious Education, Vol. 29, No. 1 (January 2007), h. 15-30.
} 
seperangkat hak asasi yang harus dihormati dan dilindungi, yang merupakan fondasi etis bagi multikulturalisme. Sebagai konsekuensi dari penjagaan terhadap hak-hak ini muncul konsep keadilan dan kesetaraan. Karena manusia diciptakan mulia (wa laqad karramnā banī $\bar{A} d a m)$ dan mempunyai kesamaan kemanusiaan (min nafs wāhidah), maka pencederaan terhadapnya dan juga hak-haknya merupakan pelanggaran terhadap kemanusiaan universal tersebut. Karenanya, untuk mencapai perdamaian di antara mereka, toleransi menjadi sebuah keharusan. Untuk melakukan hal itu, maka strategi antidiskriminas dan penghilangan prasangka negatif terhadap setiap kelompok yang berbeda-etnik, ras, budaya, dan agama-menjadi penting untuk dibentuk berdasarkan cara yang disesuaikan dengan konteks setempat.

\section{DAFTAR PUSTAKA}

Baidhawy, Zakiyuddin. "Building Harmony and Peace through Multiculturalist Theology-Based Religious Education: An Alternative for Contemporary Indonesia," British Journal of Religious Education. Vol. 29. No. 1 (January 2007), 15-30.

Coward, Harold. Pluralism in the World Religions. Oxford: Oneworld, 2000.

Fowers, Blaine J. dan Frank C. Richardson. "Why Is Multiculturalism Good?" American Psychologist. Vol. 51, No. 6 (June 1996), 609-621.

Leaman, Oliver (ed). The Qur'an: An Encyclopedia. London and New York: Routledge, 2006.

Nasr, Seyyed Hossein. The Heart of Islam: Enduring Values for Humanity. New York: Harper Collins, 2002.

Rosado, Caleb. "Toward a Definition of Multiculturalism" (28 October 2006) dalam http://rosado.net/pdf/Def_of _Multiculturalism.pdf. (Akses: 21 Februari 2012).

Tim Redaksi Bahasa Indonesia. Kamus Besar Bahasa Indonesia. Jakarta: Pusat Bahasa, 2008. 
Vol. 9, No. 1, Juni 2012: 105-120

Wehr, Hans. A Dictionary of Modern Written Arabic. ed. J. Milton Cowan, Edisi 3. New York: Spoken Language Services, 1976. 